\title{
The Restoration of Land, Studies in Ecology Vol.6, edited by A.D. Bradshaw and M.J. Chadwick. Blackwell, £13.50.
}

In the discussions of limited and renewable resources that conservationists are continually engaged in, it is often overlooked that the most basic of all our resources is clearly finite: the land. In some parts of the world large areas of land have yet to be cultivated, and the problem then is to balance the need to keep wilderness areas with the perception of an untapped resource in a hungry world. In many areas, however, and particularly in Western Europe, these reserves no longer exist. Pressure on land is then intense, and the importance of wisely using all the available land is enormous.

For this reason this book will be valuable. As its title implies it is concerned with land restoration in the widest sense, and its authors are well known as the major practitioners of the scientific approach to the problem. Here, as with so many problems, the answer lies in the soil, and they start off by explaining the features of soils that are important to healthy plant growth. Typically, misuse of land - whether by mining, dumping of waste, road-building or whatever - results in a material that lacks structure and fertility. The central message of the book is that it is usually possible to restore these essential soil properties, without great cost and without using scarce top soil, if sensible note is taken of the particular problems of the material.

The book is well written, with a minimum of technical language, and copiously illustrated. Anyone who is concerned with the re-establishment of vegetation on disturbed land should read it, and it would be nice to think that a copy was to be found on every planning officer's desk.

ALASTAIR FITTER

The Bird Business by Greta Nilsson. Animal Welfare Institute, \$5. Also available from RSPB, $£ 3$ plus postage.

It is altogether too easy to become depressed by the trade in wild animals, and this book (quite intentionally) offers no relief. Concentrating on birds it documents the staggering level of the trade, the nauseating wastage and cruelty involved, and the appalling disregard of fast-improving legal controls. It tells of Japan, which imports three million wild birds a year, and of yellow-headed parrots wrapped in newspaper, their bills bound with tape, to be smuggled into the United States. It documents the absurdity of an international airline's conviction for negligence being quashed on the grounds that the cause of a mass bird death took place outside British air space. As Dillon Ripley puts it in his introduction, wildlife laws fail because of the "constant ingenuity of humans to avoid restraint'. Yet laws can be made to bite. Exotic Newcastle disease cost $\$ 56$ million in dead chickens in California - now quarantine is taken seriously.

This is the second edition of a book first published in the USA in 1977. It has been improved by the addition of colour plates that bring home the full horror of the bird trade. Written mainly from an American angle, but with a masterly resume of the Indian trade by Tim Inskipp, it should be required reading for legislators worldwide. Unfortunately it seems unlikely to fall into the hands of any but the convinced. The book supplies the ammunition - what wildlife needs is its own big guns. Rachel Carson where are you now?

JOHN GOODERS

A Handbook for Naturalists, edited by Mark R.D. Seaward (Constable, £4.95), is a handy little reference book, with contents ranging from the historical background of the UK natural history movement to conservation organisations, books and periodicals.

In Between Earth and Paradise (Heinemann, f7.95) Mike Tomkies describes his satisfying life, and his observations and interactions with the wildlife around him seals, birds, wild cats, foxes, otters - in an isolated cabin on a west-coast Scottish island. 